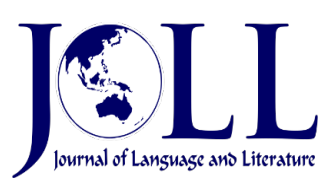

\title{
Journal of Language and Literature
}

Vol. 21 No. 2, October 2021, pp. 252-266

DOI: 10.24071/joll.v21i2.3039

Available at https://e-journal.usd.ac.id/index.php/JOLL/index

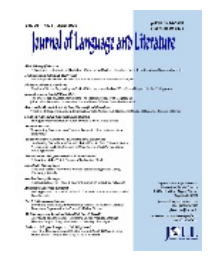

This work is licensed under a Creative Commons Attribution-ShareAlike 4.0 International License.

\section{Schematic Structure and Stance in Students' Writing in Business Communication: A Comparative Study of Native English Speaking and Iranian Students}

\author{
Arezou Bakhtiari \\ arezou.bakhtiari@ut.ac.ir \\ Faculty of Foreign Languages and Literatures, University of Tehran, IRAN
}

\begin{abstract}
This study reports on two knowledge elements of stance and schematic structure in order to help novice students increase the efficacy of their writing in business communication. With this regard, Santos' (2002) Business Letters of Negotiation Model and Hyland's (2005b) Stance Model of Interaction were drawn upon. Sixty business emails written by native English speaking (NS) and Iranian students of Business Management Departments in universities were analyzed. Two raters explored the corpus for their moves/steps frequencies and a concordance software was used in order to explore stance markers frequencies. To investigate whether Iranian and NS writers are statistically different from each other, the findings of frequencies were submitted to one-variable Chi-square test. The results showed that NS and Iranian writers are not different from each other in their content staging while they are providing information/answers or negotiating. Running counter to moves 2 and 2\&3, move 3 turned out to have different results; there was a significant difference between NS and Iranian writers in their request of information/action/favors. Results presented no significant difference between NS and Iranian writers in their employment of hedges and attitude markers of stance with regard to one-variable Chi-square test results. For boosters, Chi-square test detected a significant difference between the groups only in move 2. There was a significant difference, however, between NS and Iranian writers in their use of self-mention markers in moves 3 and $2 \& 3$. The results of this paper have both theoretical and pedagogical significance.
\end{abstract}

\author{
Article \\ information \\ Received: \\ 2 January \\ 2021 \\ Revised: \\ 5 May \\ 2021 \\ Accepted: \\ 18 May \\ 2021
}

Keywords: Genre; Social genre; Business genre; Stance; Move

\section{Introduction}

Business communication is a social activity through which professionals use language to achieve their goals (Vergaro, 2004). The need is clear; first, last and all the times it means to be able to produce texts which help the business people communicate 
effectively and "get their work done" (Ilie, Nickerson, \& Planken, 2019, p. 4). Within the perception of language as an operational whole, genre analysis has been regarded as a helpful route to underpin writing pedagogy (Hyland, 2003; Tardy, 2006). Social genre analysis of business texts can be profitable in teaching writing by broadening the notion of genre for course designers and writing instructors in generic approach to teaching in business framework. This matter galvanizes business schools into providing such mastery for participants wishing to thrive on business discourse competence (Nathan, 2013).

In particular we know little about interactions in the emerging business and professional genres of email and online synchronous conferencing. These kinds of studies would not only help us to delineate genres more precisely, but also provide important insights about the role of interaction in different forms of argument (Hyland, 2005a, p. 201).

Despite this plain need, the importance of writing in business communication received meagre attention (Millot, 2017; Warren, 2016; Zhang, 2013). In addition, a limited number of studies have been conducted to investigate the significance of interactional features of metadiscourse in business emails (Jensen, 2009) and particularly the significance of cross-cultural studies of metadiscourse in business genre is overlooked (Huang \& Rose, 2018). Investigating this important matter is augmented when it is analyzed through rhetorical moves of the text (Gillaerts \& Van de Velde, 2010; Vergaro, 2004). Apart from these, it seems that no study conducted a comparative rhetoric analysis between native English speaking (NS) and Iranian writers in order to analyze the similarities and differences of these groups when expressing their opinions and arguments in their business writing. Hence this study aimed to:

1. compare NS and Iranian writers regarding the schematic structure of their business email with following Santos' (2002) Business Letters of Negotiation Model;

2. compare NS and Iranian writers regarding their stance in their business email with following Hyland's (2005b) Stance Model of Interaction; and
3. sensitize students and writing instructors to available rhetorical options and content staging in order to help students increase the effectiveness of their writing in business communication.

\section{Review of the Literature}

Genre is a term which has been the crux of many language studies by many experts. Swales (1990) provided a working definition of genre as "a class of communicative events, the members of which share some set of communicative purposes. These purposes are recognized by expert members of the parent discourse community, and thereby constitute the rational for the genre. This rational shapes the schematic structure of the discourse and influences and constrains choice of content and style" (1990, p. 58). In genre analysis of business discourse, the analysis of the text is provided with regard to its professional context and shared communicative purpose (Ilie et al., 2019).

Bruce (2008) listed three elements of genre-based approach to discourse classification: (a) the social motivation and socially constructed elements of genre, (b) cognitive organizational structures, and (c) the actual linguistic realization of the discourse. Classification of all texts in terms of their overall social functions is affected by social genre which is anchored in social purpose of the content. On the other hand, cognitive genre determines the overall rhetorical purpose within discourse. Social genre and cognitive genre are not mutually exclusive, but essentially complementary to each other; two sides of the same coin to examine the discoursal interpretation of the particular content. Table 1 represents knowledge elements in social and cognitive genre that Bruce (2008) proposed. In this study, owing to its objective, two social elements of stance and content schemata were analyzed. It was intended to understand how writer's discoursal stance is manifested in each rhetorical move, which helps the novice writers to structure distinct rhetorical functions of their text (Liu \& Buckingham, 2018). 
Table 1. The social/cognitive genre model: Knowledge elements (Bruce, 2008)

\begin{tabular}{cc}
\hline Social genre elements & Cognitive genre elements \\
\hline context & gestalt patterns of ideas \\
epistemology & general textual patterns \\
stance & relations between propositions \\
content schemata & \\
\hline
\end{tabular}

\section{Stance}

Soliloquy actors perform to impress. Like them, writers write to capture the looks. With judicious wording, a favorable representation of writers clicks in the mind of prospective readers. This view attests to the communicative nature of writing in which writers try to obtain credibility (Hyland, 2002). Stance devices are used to transfer "personal feelings and assessments" to indicate writers' attitudes about the propositional content, their certainty of its truth, their sources of the information, and their opinion about the material under discussion (Biber, 2006, p. 99). Du Bois (2007) referred to stance with its "power to assign value to objects of interest, to position social actors with respect to those objects, to calibrate alignment between stancetakers, and to invoke presupposed systems of sociocultural value" and stated that stance is characterized through the choice of words (2007, p. 139).

Stance, owing to the guiding assumption of its value in personal revelation, has been conceptualized into a wide-ranging categories such as posture (Grabe, 1984), evidentiality (Chafe \& Nicholas, 1986), positioning (Harré \& Van Langenhove, 1999), stance (Biber \& Finegan, 1989), evaluation (Hunston \& Thompson, 2000), appraisal (Martin \& White, 2005), and metadiscourse (Hyland, 2005a). Hunston and Thompson (2000) suggested that the speakers' or writers' feeling, attitude, and viewpoint can be evaluated along a continuum consisting of four parameters of (a) good-bad scale or the value of statement, (b) certainty or the level of confidence in statements expressed by writer or speaker, (c) expectedness or how close the information is aligned with the reader/hearer's expectation, and (d) importance or how much received information is regarded as important and relevant by the reader/hearer.

A number of studies were assigned to explore stance in business discourse (e.g., Carrió-Pastor \& Calderón, 2015; Jensen, 2009; Pullin, 2013). Hyland (1998) worked on 137 CEOs' letters to see how CEOs represent their rhetorical persuasive effort. Regarding interpersonal resources and considerable frequency of hedges in the letters, he deduced that hedges were used to maintain CEOs' credibility by keeping a cautious distance from the statements. His paper concluded with underlining the importance of metadiscourse in the study of different topics of business discourse, which may be of use in better understanding of business genre. Hyland (2005a) recognized business genre as "a key area" whose metadiscoursal analyses can be of immense profit for understanding its persuasive nature (2005a, p. 201). One of the studies interested in the Hyland's (2005a) model of metadiscourse is that of Ho (2018) on the workplace request emails. In the study of metadiscourse in business genre, he identified that professionals have drawn upon interactional resources more than interactive devices and self-mentions were the most frequent devices in the emails. His findings, too, revealed that writers preferred to be the sole accountable for the actions through the use of $I$ instead of we. The prevalence of metadiscourse features was followed by hedges, boosters, engagement markers, and transitions. He also stated that professionals' willingness to hold an objective stance in their request letters resulted in low frequency of attitude markers. His paper suggested that professionals' persuasive strategies differ according to different moves of their written requests.

\section{Schematic Structure}


Learning how to participate in discourse community to achieve a communicative purpose under the command of generic approach, necessitates learning how to organize the schematic structure of the linguistic content (Samraj, 2014). The schematic structure of the content is realized in terms of moves and steps (Swales, 1990). Swales (2004) considered move as "discoursal or rhetorical unit that performs a coherent communicative function" (2004, p. 228). Similarly, Dudley-Evans and St John (1998) defined move as "a unit that relates both to the writer's purpose and to the content that s/he wishes to communicate" and step as "a lower level text unit than the move that provides a detailed perspective on the options open to the writer in setting out the moves" (1998, p. 89). Bhatia (2001) stated that moves are realized in terms of the functional values of linguistic forms, which is associated with the communicative purpose of the content. He continued that what matters in genre analysis is to realize its communicative purpose rather than its surface structure, although moves have surface lexico-grammatical realization. Some rhetorical parts of the text are forced to announce their presence to give effect to the communicative purpose and some not, hence some moves are mandatory whereas some others are optional (Swales, 1990).

The impetus for Swales' (1990) CARS (Create A Research Space) model grew out of some troubles in his original four-move model; the problem of difficulty in distinguishing moves 1 and 2 for instance. His revised model for article introduction came to be known as a landmark in generic studies (Dudley-Evans \& St John, 1998; Kwan, 2006; Paltridge, 2013). As a comprehensive model, first move introduces article purpose, next move announces the current gap in literature, and the final move comes with a prosperous solution to cover that gap. Move analysis, further, has been coupled with contrastive rhetoric to see how rhetorical organization of genre-specific corpus is at variance (e.g., Nathan, 2016; Samraj, 2014; Upton \& Connor, 2001). In their investigation of genres' "cultural expectations", Upton and Connor (2001) worked on job application letters written by students from Belgium, Finland, and the USA (2001, p. 314). In their concern for outsiders wishing to fall along members of another culture, they conducted move analysis and the analysis of politeness strategies on moves 4 and 5 which are expressing desire to have an interview and showing appreciation at the end of the letter respectively. In this respect, the American participants were the group to be more direct by using $I, y o u$, or my and formulaic in their either positive or negative politeness strategy. At the other extreme were the Belgians and the Finns were the group in between. Their study was a response to demonstrate the efficacy of commingling move analysis with the analysis of linguistic features that carry the functional values of each move.

Santos (2002), by using Swales' (1990) definition of genre, worked on the rhetorical features of a corpus of 117 business letters. Letters were classified in three groups; letters to provide information, letters to request information, and letters both to provide and to request information. He proposed a four-move model and the common linguistic characteristics employed by each move. Nathan (2016) conducted a genre move analysis on a corpus of 23 business case reports extracted from postgraduates at business schools with a view to identify any systematic association between the texts produced by NSs and non-native speakers (NNSs). His work, followed on from Swalean genre move analysis, revealed that NSs' samples were characterized by statistically significant higher frequency of modal verbs. As a result, the corpus produced by NSs was found to be rhetorically more complex than NNSs' case reports. Furthermore, Nathan suggested that high frequency of modal verb would in NSs' texts and high frequency of modal verb can in NNSs' samples can be attributed to NNSs' challenge of expressing the hypothetical-real distinction encoded by modal verbs.

\section{Methodology}

\section{The Corpus}

A total of 80 samples, all collected from either third-year or fourth-year students of Business Management Departments in universities, were collected in this study. For this, the guidelines were drawn up and 
students were expected to follow the guidelines in their writing (see Appendix A for the guidelines). The first group comprised 40 emails extracted from 2 universities in the United Kingdom. In order to reflect on the composition of these emails, the samples were collected from native speakers of English. All of them were bachelor students of Business Management. The second group consisted of 40 emails written by Iranian university students. Their major, likewise, was Business Management and all were bachelor students. All the Iranian students were presented with a required course titled English for Business Management Students at the first year of their study. This course was focused on reading comprehension with particular attention to technical terms in Business Management field.

All the emails were with the same prompt in order to control the effect of the topic on the writer's rhetorical choices (Hong \& Cao, 2014). Data were collected in a computer lab at the universities and the students were asked to write their emails within 30 minutes. All the samples were received by the author through an email. From the 80 emails submitted, based on two criteria, 60 samples were selected for this study. First, they were long enough to reflect on the original, compositional effort of the writer and second, they were not notoriously formulaic in their structuring.

Neither Iranian nor NS students in question received any formal training in how to negotiate their thoughts in one business letter. Thus the letters were written by novice Business Management students who want to enter the professional international workplace environment.

\section{Analytical Framework}

Santos' (2002) four-move model of Business Letters of Negotiation and Hyland's (2005b) Stance Model of Interaction were applied to the corpus to explore the social constructs of organizational structure and stance. In pursuing his aim to ascertain how communicative purpose is achieved, Santos (2002) developed a regularly-occurring pattern for business letters. Move 1 of this model provides the initial conditions for one business letter such as greeting the addressee. Move 2 of this model serves to provide information which can be either new or already known to both counterparts. Preponderant signals of this move are direct discourse, first person signals, and the name of employees (Santos, 2002).

Move 3 with its optional steps seeks information/action/favors. In Santos opinion, requesting can be submitted through interrogating, imperatives, or declaratives and if the strength of the request is low, these requests can come with could, would, would like, please, etc. Need is another linguistic possibility when the strength of the request is high (Santos, 2002). There are some steps and sub-steps common to moves 2 and 3 (hereafter, move 2\&3), by which the delicacy of negotiating is brought into play. Step vi-c-i, for instance, keeps the exchange of ideas open to flexibility or availability. Move 4 portrays the end of the business letter. It should be noted that in this study moves 1 and 4 of this model were not investigated; this was because moves 2 and 3 are centered upon the rhetorical pattern of the communicative purpose and moves 1 and 4 in this model work as the frame of these moves (Santos, 2002). Table 2 represents the schematic structure of Business Letters of Negotiation developed by Santos (2002). 
Table 2. Schematic structure of Business Letters of Negotiation (Santos, 2002)

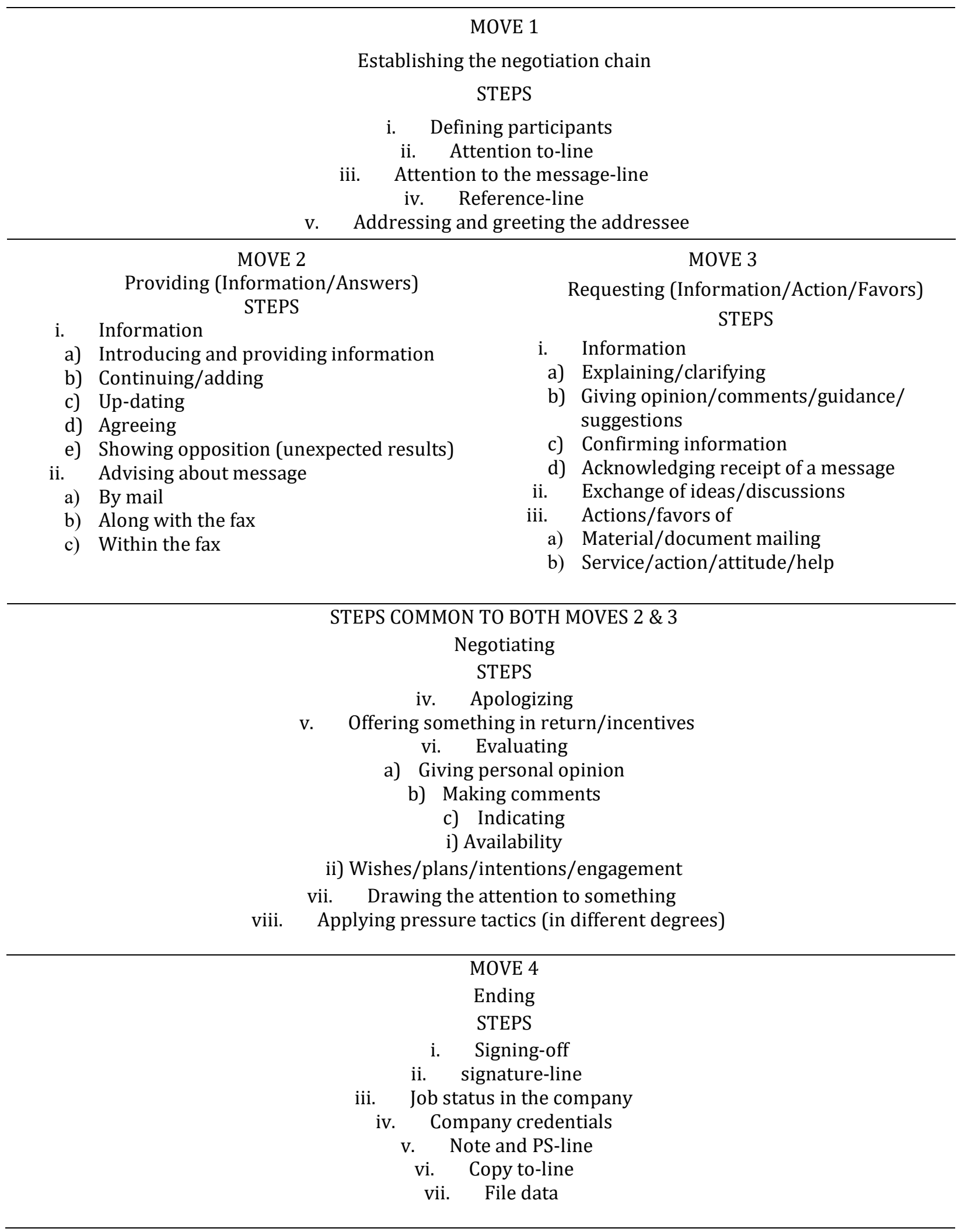

Seeing metadiscourse with its significant function to facilitate communication in the process of unfolding text as discourse, Hyland (2005a) elaborated on its twofold categories of interactive and interactional resources. Interactive resources are connected with the 
management of text organization in Hyland's (2005a) model. In this model, interactional resources enlighten readers about the writer's commitment, accountability, attitude, presence, and engagement in written interaction. It includes five components of hedges, boosters, attitude markers, selfmentions, and engagement markers. When writers use language to help them construct plausible reasoning and evade full commitment to propositional meaning, hedges are used (Hyland, 2005b). They also keep propositional meaning open for readers' opinion involvement (Gillaerts \& Van de Velde, 2010). Boosters on the other hand, block out tentative reasoning and increase writer's certainty about the statements (Hu \& Cao,
2015). As epistemic strategy, using hedges and boosters allows writers to make a balance in their claims, hence to keep readers' endorsement (Hyland, 2005b). Attitude markers, as the name indicates, are used to reveal writers' attitudinal values to propositions (Hyland \& Jiang, 2018). Interpolation of self-mention markers which are first person pronouns and possessives, is to signal writer's "authorial identity" (Hyland, 2002, p. 1091). Engagement markers are to invite readers explicitly to accompany writers through the text (Hyland, 2005a). Hyland (2005b), subsequently, set the interaction model with its two components of stance and engagement. Table 3 shows the stance model of interaction developed by Hyland (2005b).

Table 3. Stance features of interaction (Hyland, 2005b)

\begin{tabular}{ccc}
\hline Stance Features & Function & Examples \\
\hline Hedges & Withhold commitment & Might; perhaps; possible; about \\
Boosters & Emphasize certainty or close dialogue & In fact; definitely; it is clear that \\
Attitude markers & Express writer's attitude to proposition & Unfortunately; surprisingly \\
Self-mentions & Explicit reference to author(s) & I; we; me; our \\
\hline
\end{tabular}

\section{Procedure}

After collecting the required corpus, all the letters were assessed through the process of repeated, intensive reading of each sample to recognize moves/steps. For this, two raters (authors of this article) cooperated with each other to attenuate subjectivity. For stance markers, the emails were analyzed using the concordance software AntConc (Anthony, 2011). The search for stance markers included both American and British spelling of the words. To receive an assurance a step further, afterwards, $20 \%$ of the samples were assessed independently by both raters through the process of repeated reading to ensure the metadiscoursal function of the concordance items with inter-rater agreement of $97 \%$. Then, Statistical significance was analyzed by one-variable Chi-square test.

\section{Results and Discussion}

\section{Schematic structure of emails}

In order to understand whether there is any difference between NS and Iranian writers when they are providing information/answers, the Chi-square probability value indicated no significant difference between the groups (see Table 4). Expectedly, no one used step i-d in their writing, as there was nothing in the guidelines to be agreed with (see Appendix A). Step ii and its sub-steps, moreover, were not considered to be important by both groups to be included in their emails. Step i-e, showing opposition, was present potently among all samples and signified that all writers regardless of their linguistic background, pointed at unexpected results in their writing.

The Chi-square probability value denoted that there is a significant difference (log likelihood $=6.352, p<0.05$, see Table 4) between NS and Iranian writers in their rhetorical organization when they are requesting information/action/favor. Neither 
of the groups used the acknowledging receipt of the message in their writing. The frequency of steps in move 3 was more in the emails written by Iranian students because they provided the reader with more information (i.e., detailed move). Compared to Iranian students, NS students used fewer steps in this move. This might suggest Hinds' (1987) statement about writer-responsible rhetoric in which the writer provides the reader with more information to support the claim and reader-responsible rhetoric in which the writer expects the reader to infer the claim from the text.

Investigating whether there is any difference between NS and Iranian writers in their attempt to negotiate, the Chi-square probability value showed no significant difference between NS and Iranian writers in their use of negotiating move (see Table 4). The first point to mention is that no one used step iv in their writing, as in the email about which writers were asked to write, there was nothing related to making apologies (see Appendix A). Iranian writers had a propensity to exert pressure to get what they want whereas NS students adopted this tactic less than Iranian writers. The presence of If-clauses and in case of in large numbers in Iranian writers' emails was noticeable. These hypothetical expressions are indicative of writer's flexibility to exchange the information with the addressee (Santos, 2002). In line with that, Iranian writers were more likely to announce their own opinions, meaning that step vi-a was employed by them more than their NS peers. NS students, unlike Iranian students, preferred to make comments more than making personal opinions; they used step vi-b more than Iranian writers. Table 4 represents the frequency of steps in all moves and one-variable Chi-square statistical results.

Table 4. The frequency of steps in moves and one-variable Chi-square statistical results

\begin{tabular}{cccccc}
\hline Move Type & $\begin{array}{c}\text { NS } \\
\text { students }\end{array}$ & $\begin{array}{c}\text { Iranian } \\
\text { students }\end{array}$ & \multicolumn{2}{c}{ One-Variable Chi-square Results } \\
\hline Move 2 & 84 & 86 & Chi-Square $=.024^{\mathrm{b}}$ & df $=1$ & Asymp. Sig. $=.878$ \\
\hline Move 3 & 74 & 108 & Chi-Square $=6.352^{\mathrm{b}}$ & df $=1$ & Asymp. Sig. $=.012$ \\
\hline Move 2\&3 & 89 & 111 & Chi-Square $=2.420^{\mathrm{b}}$ & df $=1$ & Asymp. Sig. $=.120$ \\
\hline
\end{tabular}

\section{Stance markers of interaction}

\section{Hedges}

In order to establish whether NS and Iranian writers are different in their attempt to extricate themselves from firm commitment to propositional content by using hedges, the Chi-square probability value indicated that there is no significant difference between NS and Iranian writers in their employment of hedges (see Table 5). However, the Iranian students tempered their responsibility for the information by using hedges more than the NS students. In move 3, both groups used hedges nearly with the same approach in requesting. Unlike move 2, hedges were used more in the emails of NS writers when they were negotiating their comments. The preference of would and may that were used by NS students in the emails was noticeable whereas the Iranian students preferred employing should (see examples 1 and 2). With the use of epistemic would, the veracity of the propositions is suggested (Ward, Birner \& Kaplan, 2003). This belief is augmented by the use of may rather than might whose degree of certainty is less than may (Palmer, 1990). Hedges appeared more frequently in moves 3 and $2 \& 3$ and this can be attributed to the function of these moves; this may provide evidence that students prefer to take cautionary approach while asking for action or negotiating. Rahimpour and Faghih (2009) explored the use of metadiscourse linguistic markers in research articles written by NS and Iranian writers and concluded that hedges are the most frequent stance marker used by both groups. However this finding was not corroborated by the present study, which can be on account the difference between the nature of academic genre and business genre. Table 5 shows the frequency of hedges in all moves and its statistical results. In move 2, the Fisher's exact test was an appropriate alternative to Chi-square test 
because the frequency of steps in NSs' emails was less than 5 (Mackey \& Gass, 2005).
(1) I would be grateful to have your solution for this problem. (NS student)

(2) The ordered capacitors should be delivered to our customer as soon as possible. (Iranian student)

Table 5. The frequency of hedges in moves and one-variable Chi-square statistical results

\begin{tabular}{|c|c|c|c|}
\hline Move Type & $\begin{array}{c}\text { NS } \\
\text { students }\end{array}$ & $\begin{array}{l}\text { Iranian } \\
\text { students }\end{array}$ & One-Variable Chi-square Results \\
\hline Move 2 & 2 & 5 & $\begin{array}{c}\text { Chi-Square }=1.286^{b} \quad \text { df }=1 \quad \text { Asymp. Sig. }=.257 \\
\text { Fisher's Exact Test } \quad \text { Exact Sig. }=0.453\end{array}$ \\
\hline Move 3 & 20 & 18 & Chi-Square $=.105^{b} \quad \mathrm{df}=1 \quad$ Asymp. Sig. $=.746$ \\
\hline Move $2 \& 3$ & 25 & 18 & Chi-Square $=1.140^{b} \quad \mathrm{df}=1 \quad$ Asymp. Sig. $=.285$ \\
\hline Totals & 47 & 41 & Chi-Square $=.409 \mathrm{~b} \quad \mathrm{df}=1 \quad$ Asymp. Sig. $=.522$ \\
\hline
\end{tabular}

\section{Booster}

Chi-square probability value showed a significant difference (log likelihood $=6.231, p$ $<0.05$, see Table 6) between NS and Iranian writers while providing information in move 2 in their attempt to express themselves with assurance by using boosters. In addition of Chisquare test, the Fisher's exact test was used because the NSs' use of boosters was less than the frequency of 5 and Chi-square test result was backed up by this test (Mackey \& Gass, 2005). The Iranian students employed boosters more than the NS students to fortify their arguments in their providing information/answers. Akin to the frequency pattern of hedges in move 3 (see Table 5), NS and Iranian students used boosters in a similar manner in this move (see Table 6). This would suggest that both groups adopted a similar approach to use epistemic strategy for requesting. More confidence in negotiating is the characteristic that raw frequencies revealed for NS participants of this study. However, statistical analysis showed no significant difference between the two groups in moves 3 and $2 \& 3$ (see Table 6). Cognitive verbs are present in both categories of boosters and hedges. The proportion of think and assume in the emails of Iranian writers was noticeable in comparison to the proportion of believe in the emails of the NS students (see examples 3 and 4). Fetzer and Johansson (2010) stated that cognitive verbs are frequent in argumentative discourse in which the validity of claims is negotiated. They concluded that among cognitive verbs, think can fulfill a dual function of both attenuating and boosting the arguments whereas believe solely functions as a booster. Boosters displayed the lowest number of frequency in total among stance markers in the emails written by both groups. The infrequent use of boosters would imply that neither NS nor Iranian students used these devices with large numbers to increase "the force of statements" in their emails (Pullin, 2013, p. 5). Table 6 represents the frequency of boosters in all moves and the statistical results of these frequencies.

(3) We think you should take the necessary actions in order to avoid such problems. (Iranian student)

(4) I believe the mistake has been made by your Logistics Department. (NS student)

Table 6. The frequency of boosters in moves and one-variable Chi-square statistical results

\begin{tabular}{lllll}
\hline Move Type & $\begin{array}{l}\text { NS } \\
\text { students }\end{array}$ & $\begin{array}{l}\text { Iranian } \\
\text { students }\end{array}$ & One-Variable Chi-square Results \\
\hline Move 2 & 2 & 11 & $\begin{array}{l}\text { Chi-Square=6.231 } \\
\text { (1) }\end{array}$ & df $=1 \quad$ Asymp. Sig. $=.013$ \\
& & Fisher's Exact Test & Exact Sig.=0.022 \\
\hline
\end{tabular}




\begin{tabular}{llllll}
\hline Move 3 & 6 & 5 & Chi-Square $=.091^{\mathrm{b}}$ & $\mathrm{df}=1$ & Asymp. Sig. $=.763$ \\
\hline Move $2 \& 3$ & 13 & 6 & Chi-Square $=2.579^{\mathrm{b}}$ & $\mathrm{df}=1$ & Asymp. Sig. $=.108$ \\
\hline Totals & 21 & 22 & Chi-Square $=.023^{\mathrm{b}}$ & $\mathrm{df}=1$ & Asymp. Sig. $=.879$ \\
\hline
\end{tabular}

\section{Attitude Markers}

Chi-square probability values for moves 2,3 , and $2 \& 3$ represented that NS and Iranian writers are not different from each other when they express affective attitude to the propositions in their business emails (see Table 7). Attitude markers were virtually the only stance marker whose resources were distributed among all moves/steps of both groups' corpus with relative uniformity.
Similar to Ho's (2018) finding, low frequency of attitude markers might be aligned with writers' concern for maintaining an objective stance in professional community. However, Attitude markers appeared more frequently in move 2. This may be suggestive of both groups' preference to mark their personal attitudes more explicitly while providing information. Table 7 represents the frequency of attitude markers in all moves and onevariable Chi-square statistical results.

Table 7. The frequency of attitude markers in moves and one-variable Chi-square statistical results

\begin{tabular}{|c|c|c|c|}
\hline Move Type & NS students & Iranian students & One-Variable Chi-square Results \\
\hline Move 2 & 14 & 12 & $\begin{array}{l}\text { Chi-Square }=.154^{b} \quad \mathrm{df}=1 \text { Asymp. Sig. } \\
=.695\end{array}$ \\
\hline Move 3 & 8 & 6 & $\begin{array}{l}\text { Chi-Square }=.286^{b} \quad \mathrm{df}=1 \text { Asymp. Sig. } \\
=.593\end{array}$ \\
\hline Move $2 \& 3$ & 7 & 8 & $\begin{array}{l}\text { Chi-Square }=.067^{b} \quad \mathrm{df}=1 \text { Asymp. Sig. } \\
=.796\end{array}$ \\
\hline Totals & 29 & 26 & $\begin{array}{l}\text { Chi-Square }=.164^{b} \quad \mathrm{df}=1 \text { Asymp. Sig. } \\
=.686\end{array}$ \\
\hline
\end{tabular}

\section{Self-Mention Markers}

No notable difference could be identified between the groups in their use of selfmention devices in move 2 , suggesting that both groups inserted their self explicitly somewhat with the same style while providing information in their emails. However, the Chi-square probability value indicated that there is a significant difference $(\log$ likelihood $=20.180, \mathrm{p}<0.05$, see Table 8) between the participants in their employment of self-mention markers in move 3 . The Chisquare probability value, moreover, indicated a significant difference (log likelihood $=$ 13.376, p < 0.05, see Table 8) between NS and Iranian writers in their use of self-mention markers in move $2 \& 3$. Interestingly, the Iranian students made use of self-mention markers more in moves 3 and $2 \& 3$. It possibly reflects the Iranian students' inclination to mark their self explicitly when they want to request information/action/favors or negotiate in their business emails. Both groups preferred to use self-visibility strategy through the use of self-mention markers more when it comes to negotiating move in their emails. This was a plan developed by both groups in order to attain their goals in negotiation which is "distinguished as a strategic process" (Jensen, 2009, p. 5). At this juncture, it is important to mention that the Iranians' visible stance was manifested particularly through the use of we whereas the NSs' stance was mainly backed up by their use of I (see examples 5 and 6). About selfmentions, there seems that the Iranians' malleability runs somewhat counter to the NSs' tenacity. Furthermore, the high frequency of I in NSs' emails can be indicative of their "more personalised professional attitude" (Santos, 2002, p. 186). Table 8 reveals the frequency of self-mention markers in all moves and one-variable Chi-square statistical results.

(5) I had never seen such a mistake in cooperating with you before. (NS student) 
(6) We were surprised when the quantity of the capacitors were fewer than expected. (Iranian student)

Table 8.

The frequency of self-mention devices in moves and one-variable Chi-square statistical results

\begin{tabular}{|c|c|c|c|}
\hline Move Type & NS students & Iranian students & One-Variable Chi-square Results \\
\hline \multirow[t]{2}{*}{ Move 2} & 71 & 96 & Chi-Square $=3.743^{\mathrm{b}} \quad \mathrm{df}=1$ Asymp. \\
\hline & & & Sig. $=.053$ \\
\hline \multirow[t]{2}{*}{ Move 3} & 52 & 109 & Chi-Square $=20.180^{\mathrm{b}} \quad \mathrm{df}=1$ \\
\hline & & & Sig. $=.000$ \\
\hline \multirow[t]{2}{*}{ Move $2 \& 3$} & 82 & 136 & Chi-Square $=13.376^{\mathrm{b}} \quad \mathrm{df}=1$ \\
\hline & & & Sig. $=.000$ \\
\hline \multirow[t]{2}{*}{ Totals } & 205 & 341 & Chi-Square $=33.875^{b} \quad d f=1$ \\
\hline & & & Sig. $=.000$ \\
\hline
\end{tabular}

This study investigated two elements of social genre in terms of the stance of the Iranian and NS students in different moves of one business email.

With regard to content staging of students' emails, there was no difference between NS and Iranian students when providing information/answers or negotiating. In contrast, these two groups were different from each other while asking for information/action/favors in their writing (see Table 4). Requesting in workplace emails is important because an appropriate request can ensure compliance with the requestor and develop a rapport with the requestee (Ho, 2018). In addition, our study of schematic structure has shown that Santos' (2002) model of Business Letters of Negotiation can account for moves in different corpus. Nonetheless, one limitation was discovered by this study; we experienced difficulty in distinguishing between steps i-b (asking for opinion) and iiib (asking for attitude) in move 3 in some emails because there was no clear definition provided by Santos (2002) for these steps.

How to use language to extricate from full commitment to propositions, is a strategy called using hedges. Statistical report showed that neither Iranian nor NS students used this tactic with high frequency at different moves/steps of their emails (see Table 5). Whereas hedges mark writer's reluctance to propositional content, boosters mark writer's assurance about what is written (Hyland \&
Tse, 2004). All the emails were analyzed to find out whether NS and Iranian writers are different in emphasizing the certainty about propositions. In so doing, the statistical report detected that these groups are different in their use of boosters in providing information/answers move (see Table 6). However, both NS and Iranian writers allowed for alternative voice about their propositions in moves 3 and $2 \& 3$. To see how the two groups are different in announcing their own attitudes, statistical report showed no significant difference between NS and Iranian participants when expressing their affective point of views towards the propositional content (see Table 7). This study, furthermore, explored the use of first person pronouns and possessive adjectives in NS and Iranian students' writing. Statistical report, by analyzing discoursal self frequencies, represented a significant difference between NS and Iranian writers about their use of selfmention markers in moves 3 and $2 \& 3$ (see Table 8). Iranian students had a tendency to present themselves on the stage explicitly more than NS students, however, their visible self was tempered through the use of we. This can be the result of cultural and social viewpoint on self (Hyland, 2002).

Participants' overall sparse use of stance markers might be germane to three possible reasons. First, Writers' rhetorical choices can be made under the influence of "certain values and beliefs that support particular identities" originating from their home cultures (Hyland, 
2002, p. 1092). How individuals use linguistic forms to create stance is relevant to one's epistemic or interpersonal stance and personal style is couched in one's habitual stream of stance within a specific interaction (Jaffe, 2009). This suggests the importance of socio-cultural context in particular genre and social community in adopting specific rhetorical resources in writing.

Second, it might provide evidence for rhetorical dynamics of professional context (Hyland \& Tse, 2004). Analyzing discourse strategies of sales promotion letters, Vergaro (2004) adduced that the lack of metadiscourse elements in business communication is possibly as a consequence of genre-based features. Hyland and Jiang (2018) reported in their study that "metadiscourse is essentially an open category to which writers are able to add new items according to the needs of the context and due to insider opacity the analyst may never recover all intended metadiscoursal meanings" (2018, p. 21). Ho (2018) mentioned that reliance on a list proposed by Hyland (2005a) would lead to our ignorance of some other expressions with metadiscursive function owing to their local linguistic context.

Finally, it may reflect students' ignorance of stance importance. Hyland in his lifelong view of community-approved writing, commented that text quality is augmented by writers' understanding of how words convene to put forth rhetorical consequences. By this, transition from theory to practice can be brought into consideration. In the process of transferring theories into the classrooms, students can be made cognizant of text dialogical position with intelligent use of stance markers to augment their persuasive objectives (Crosthwaite, Cheung, \& Jiang, 2017). As a pragmatic category, metadiscourse is context-dependent and its markers set the text to its context (Hyland \& Tse, 2004). Paltridge and his colleagues at University of Sydney found ethnographies useful in writing courses to examine the rhetorical context of students' writing. In this process, students will gain insight into the values, expectations, and assessment process of their texts by working as a researcher. Similarly, in writerly reading the text, the writer is provided with the chance to be aware of how rhetorical choices are made through the process of constantly revising that text (Hirvela, 2004). In other words, it means that in generic-based teaching of writing, the writers learn how to organize the schematic structure of the text with appropriate stance by placing themselves in the position of both reader and writer in order to notice the writer's purpose, reader's expectation, and available rhetorical options to construct that text through various moves. However, Johns (2008) voiced her concern over prescriptivism in educational genre settings with emphasizing "to educate, rather than train, novice academic students" (2008, p. 246) (educational rather than training approach were the terms already used by Flowerdew in 1993). In her discussion of how we can develop a flexible rhetorical knowledge applicable in too many diverse situations, she offered two promising alternatives: one is interdisciplinary learning communities and the other is general EAP and disciplinary grouping of literacy responses into macrogenres. They represent respectively encouraging students to assume the role of researcher to explore the rhetorical values under the auspices of their instructor and using Carter's (2007) disciplinary macrogenres to stimulate educational frames in which genre awareness is valued. Likewise, Santos (2002) believed that genre approach to teaching a language can be of great use for language description rather than language prescription. Developing business competence in business intercultural and multilingual communication can flourish in the classrooms if the students have business knowledge within business context. This suggests that students can be trained to act rhetorically flexible in particular assignment to achieve their goals and cases are promising approaches in forging the link between classrooms and the real world (Kankaanranta \& Louhiala-Salminen, 2010).

\section{Conclusion}

The goal of this study was to investigate the differences between NS and Iranian students regarding their stance pattern in different moves of their business letters in order to help novice students with their communication in international vibrant 
business world. The differences and similarities that have been revealed by this study might imply students' connection to communal assumption in their maneuver of language to consolidate the social persona. Texts occur in their discoursal settings and this is to credit Swales' (1990) notion of discourse community, creating a value system that gives shape to the sense of self within readers of that specific discourse community.

In terms of theoretical significance, this study boosted confidence in the reliability of Santos' (2002) model of Business Letters of Negotiation. However, based on the results of this study, there seems that the reliability of Hyland's (2005b) stance model expressions is tentative in business framework, which signals the need for further related studies reanalyzing the reliability of the expressions of this model in business genre.

In terms of pedagogical significance, the findings of this study can be of use for novice writers in business prose to heighten their awareness of the availability of rhetorical options and staging frameworks in order to enhance the effectiveness of their writing in particular discourse community. With this study, we hope that course designers and writing instructors take cognizance of social genre importance by broadening the notion of genre in generic approach to teaching in business framework. Clear thinking is a requisite of clear writing and writing instructors can polish discourse competence up in novice writers by generic training of business communication.

This study was conducted with two groups of participants. The results may need to be corroborated by further studies on a larger scale of data and it would be more comprehensive if the future studies carry the ethnographic approach forward in generic analysis of writing. The present study did not examine the occurrence of stance markers in steps; we acknowledge that a more grained move/step analysis combined with stance markers can be pedagogically more profitable.

\section{References}

Anthony, L. (2011). AntConc (Version 3.2.2) [Computer Software]. Tokyo, Japan: Waseda University.

Bhatia, V. K. (2001). Analysing genre: Some conceptual issues. In M. Hewings (Ed.), Academic writing in context: Implications and applications (pp. 79-92). Birmingham: University of Birmingham Press.

Biber, D. (2006). Stance in spoken and written university registers. Journal of English for Academic Purposes, 5(2), 97-116.

Biber, D., \& Finegan, E. (1989). Styles of stance in English: Lexical and grammatical marking of evidentiality and affect. Text, 9, 93-124.

Bruce, I. (2008). Academic writing and genre: A systematic analysis. London: Continuum.

Carrió-Pastor, M. L., \& Calderón, R. M. (2015). A contrastive analysis of metadiscourse features in business e-mails written by non-native speakers of English. Procedia-Social and Behavioral Sciences, 173, 214-221.

Carter, M. (2007). Ways of knowing, doing, and writing in the disciplines. College Composition and Communication, 58(3), 385-418.

Chafe, W. L., \& Nichols, J. (Eds.). (1986). Evidentiality: The linguistic coding of epistemology. Norwood, NJ: Ablex.

Crosthwaite, P., Cheung, L., \& Jiang, F. K. (2017). Writing with attitude: Stance expression in learner and professional dentistry research reports. English for Specific Purposes, 46, 107-123.

Du Bois, J. W. (2007). The stance triangle. In R. Englebretson (Ed.), Stancetaking in discourse: Subjectivity, evaluation, interaction (pp. 139-182). Amsterdam: Benjamins.

Dudley-Evans, T., \& St John, M. J. (1998). Developments in English for specific purposes: A multi-disciplinary approach. Cambridge: Cambridge University Press.

Fetzer, A., \& Johansson, M. (2010). Cognitive verbs in context: A contrastive analysis of English and French argumentative discourse. International Journal of Corpus Linguistics, 15(2), 240-266. 
Flowerdew, J. (1993). An educational, or process, approach to the teaching of professional genres. ELT Journal, 47, 30516.

Gillaerts, P., \& Van de Velde, F. (2010). Interactional metadiscourse in research article abstracts. Journal of English for Academic Purposes, 9(2), 128-139.

Grabe, W. (1984). Towards defining expository prose within a theory of text construction (Unpublished doctoral dissertation). University of Southern California, Los Angeles.

Harré, R., \& Van Langenhove, L. (1999). Positioning theory: Moral contexts of intentional action. Oxford, UK: Blackwell.

Hinds, J. (1987). Reader versus writer responsibility: A new typology. In U. Connor, \& R. B. Kaplan (Eds.), Writing across languages: Analysis of L2 text (pp. 141-152). Reading, MA: Addison-Wesley.

Hirvela, A. (2004). Connecting reading \& writing in second language writing instruction. Ann Arbor, MI: University of Michigan Press.

Ho, V. (2018). Using metadiscourse in making persuasive attempts through workplace request emails. Journal of Pragmatics, 134, 70-81.

Hong, H., \& Cao, F. (2014). Interactional metadiscourse in young EFL learner writing: A corpus-based study. International Journal of Corpus Linguistics, 19(2), 201-224.

Hu, G., \& Cao, F. (2015). Disciplinary and paradigmatic influences on interactional metadiscourse in research articles. English for Specific Purposes, 39, 12-25.

Huang, Y., \& Rose, K. (2018). You, our shareholders: metadiscourse in CEO letters from Chinese and Western banks. Text \& Talk, 38(2), 167-190.

Hunston, S., \& Thompson, G. (Eds.), (2000). Evaluation in text: Authorial stance and the construction of discourse. Oxford: Oxford University Press.

Hyland, K. (1998). Exploring corporate rhetoric: Metadiscourse in the CEO's letter. Journal of Business Communication, 35(2), 224-245.

Hyland, K. (2002). Authority and invisibility: Authorial identity in academic writing. Journal of Pragmatics, 34(8), 1091-1112.
Hyland, K. (2003). Genre-based pedagogies: A social response to process. Journal of Second Language Writing, 12(1), 17-29.

Hyland, K. (2005a). Metadiscourse: Exploring interaction in writing. London: Continuum.

Hyland, K. (2005b). Stance and engagement: a model of interaction in academic discourse. Discourse Studies, 7(2), 173192.

Hyland, K., \& Jiang, F. K. (2018). “In this paper we suggest": Changing patterns of disciplinary metadiscourse. English for Specific Purposes, 51, 18-30.

Hyland, K., \& Tse, P. (2004). Metadiscourse in academic writing: A reappraisal. Applied Linguistics, 25(2), 156-177.

Ilie, C., Nickerson, C., \& Planken, B. (2019). Teaching Business Discourse. Basingstoke: Palgrave Macmillan.

Jaffe, A. (2009). Stance: Sociolinguistic perspectives. Oxford, England: Oxford University Press.

Jensen, A. (2009). Discourse strategies in professional e-mail negotiation: A case study. English for Specific Purposes, 28(1), 4-18.

Johns, A. M. (2008). Genre awareness for the novice academic student: An ongoing quest. Language Teaching, 41, 237-252.

Kankaanranta, A., \& Louhiala-Salminen, L. (2010). "English? - Oh, it's just work!": A study of BELF users' perceptions. English for Specific Purposes, 29, 204-209.

Kwan, B. S. (2006). The schematic structure of literature reviews in doctoral theses of applied linguistics. English for Specific Purposes, 25(1), 30-55.

Liu, Y., \& Buckingham, L. (2018). The schematic structure of discussion sections in applied linguistics and the distribution of metadiscourse markers. Journal of English for Academic Purposes, 34, 97109.

Mackey, A., \& Gass, S. (2005). Second language research: Methodology and design. Mahwah, New Jersey: Lawrence Erlbaum.

Martin, J. R., \& White, P. R. R. (2005). The language of evaluation: Appraisal in English. London: Palgrave Macmillan.

Millot, P. (2017). Inclusivity and exclusivity in English as a Business Lingua Franca: The expression of a professional voice in email 
communication. English for Specific Purposes, 46, 59-71.

Nathan, P. (2013). Academic writing in the Business School: The genre of the business case report. Journal of English for Academic Purpose, 12, 57-68.

Nathan, P. (2016). Analysing options in pedagogical business case reports: Genre, process and language. English for Specific Purposes, 44, 1-15.

Palmer, F. (1990). Modality and the English modals. London: Longman.

Paltridge, B. (2013). Genre and English for specific purposes. In B. Paltridge \& S. Starfield (Eds.), Handbook of English for specific purposes (pp. 347-366). West Sussex, England: Wiley-Blackwell.

Pullin, P. (2013). Achieving "comity": The role of linguistic stance in business English as a lingua franca (BELF) meetings. Journal of English as a Lingua Franca, 2(1), 1-23.

Rahimpour, S., \& Faghih, E. (2009). Contrastive rhetoric of English and Persian written texts: Metadiscourse in applied linguistics research articles. Rice Working Papers in Linguistics, 1(16), 92-107.

Samraj, B. (2014). Move structure. In K. P. Schneider, \& A. Barron (Eds.), Pragmatics of discourse (pp. 385-405). Berlin: Mouton de Gruyter.

Santos, V. B. M. P. dos (2002). Genre analysis of business letters of negotiations. English for Specific Purposes, 21(2), 167-19.

Swales, J. M. (1990). Genre analysis: English in academic and research settings. Cambridge: Cambridge University Press.

Swales, J. M. (2004). Research genres: Explorations and applications. Cambridge: Cambridge University Press.

Tardy, C. M. (2006). Researching first and second language genre learning: A comparative review and a look ahead. Journal of Second Language Writing, 15(2), 79-101.

Upton, T. A., \& Connor, U. (2001). Using computerized corpus analysis to investigate the textlinguistic discourse moves of a genre. English for Specific Purposes, 20(4), 313-329.

Vergaro, C. (2004). Discourse strategies of Italian and English sales promotion letters. English for Specific Purposes, 23(2), 181-207.
Ward, G., Birner, B. J., \& Kaplan, J. P. (2003). A pragmatic analysis of the epistemic would construction in English. In R. Facchinetti, M. Krug, \& F. Palmer (Eds.), Modality in Contemporary English (pp. 71-79). Berlin: Mouton De Gruyter.

Warren, M. (2016). Signalling intertextuality in business emails. English for Specific Purposes, 42, 26-37.

Zhang, Z. (2013). Business English students learning to write for international business: What do international business practitioners have to say about their texts? English for Specific Purposes, 32, 144-156.

\section{Appendix}

Guidelines for students to write their emails You are requested to write an email based on the following guidelines. These emails would be collected and their structure would be analyzed thoroughly.

Guidelines:

You are working as a foreign correspondent in one company. Your company received a consignment of 120 capacitors whereas you had ordered 150 of them. In your email, please explain the situation and demand the capacitor manufacturer to send the rest of capacitors. As compensation, you may ask them to pay you for delay.

In your email, please bear in mind:

- These capacitors are vital in industrial plants and no mistake in their delivery is justifiable.

- You and the capacitor manufacturer have been doing business for a long time without encountering such a mistake.

- It should contain 150 up to 180 words.

- Formulaic statements are not recommended.

- It should be addressed to imaginary person named Michael.

- The confidentiality of your information is highly guaranteed. Name............. Major............. University degree. 